\title{
Sustainable Development in Maramures County
}

\section{Corina Rădulescu ${ }^{1,2}$, Rita Toader ${ }^{1,2, \dagger}$, Gratiela Boca ${ }^{1,2, \dagger, *}$, Madela Abrudan ${ }^{3, \dagger}$, Cristian Anghel ${ }^{1,2, \dagger}$ and Diana Cezara Toader ${ }^{4}$}

1 Department of Economics, Technical University of Cluj Napoca, Bulevardul 21 Decembrie 1989 128-130, Cluj-Napoca 400604, Romania; E-Mails: corina.radulescu@ cunbm.utcluj.ro (C.R.); rita.toader@cunbm.utcluj.ro (R.T.); cristiananghel@cunbm.utcluj.ro (C.A.)

2 Department of Economics, North Center University of Baia Mare, 76 Victoriei street, Baia Mare 430122, Romania

3 Faculty of Economics, University of Oradea, Oradea 410087, Romania; E-Mail: mabrudan@uoradea.ro

4 Romanian Academy of Economics Bucharest, Bucharest 010374, Romania; E-Mail: diana.cezara@gmail.com

$\dagger$ These authors contributed equally to this work.

* Author to whom correspondence should be addressed; E-Mail: bocagratiela@ cunbm.utcluj.ro or bocagratiela@yahoo.com; Tel.: +40-724-341-344.

Academic Editor: Marc A. Rosen

Received: 25 February 2015 / Accepted: 22 May 2015 / Published: 15 June 2015

\begin{abstract}
We argue that a new type of adaptive change management is needed in Romania, in which social and territorial cohesion are key elements of governance, in accordance with sustainable development requirements. Based on critical analysis and comparative study, the paper investigates, using several approaches, the possibility to select those elements that enable determining a viable managerial sustainable development "model" for communities in Maramures County, Romania. New trends worldwide, and the multidimensional aspects of sustainable development of communities, were the subject of examination, through a regional polycentric approach, which led to a new model proposed by the authors. The result is a conceptual integrated model which promotes a balance of interaction between systems - economic, human, environmental and technological—in a dynamic, flexible and functional process.
\end{abstract}


Keywords: sustainable development; county model; strategy model; environment; analysis resources; economic development

\section{Introduction}

Although more than seven years have passed since the accession of Romania to the European Union, implementing a strategy for sustainable development of communities causes considerable debate and is still in the early stages of formation. In the Maramures region of Romania, a former mining area with high ecological clashes, mine closures have taken place, leaving behind areas with social, environmental and economic problems. For a new approach to sustainability with maximum efficiency, in line with EU policies, new strategic thinking is needed that incorporates regional concerns and accelerates the process of alignment with global requirements.

The paper proposes that on the basis of an objective analysis of the main socio-economic situations arising from previous years, there are strategies that can establish public management in Maramures County. Also, the authors examine regional territorial dimensions of sustainable development and recommend a suitable integrative model according to the current requirements.

The literature abounds with theories, models, and concepts on sustainable development at a community level. The very definition of sustainable development places people at the center of society, as well as the living environment and its care. Sustainable development is the development that meets the needs of the present without compromising the ability of future generations to meet their own needs [1,2]. Estimates of what the needs of society are, and what the needs of future generations will be are therefore required. Moreover, general models of sustainable development suggests that there can be no independent factors that lead to sustainability without a permanent inter-relationship between them, as shown in Figure 1.

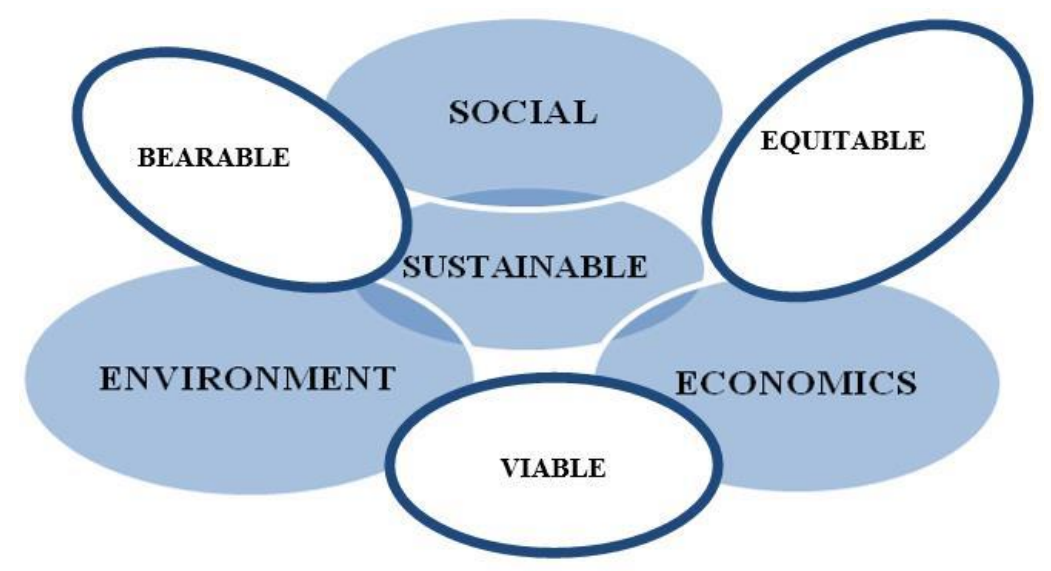

Figure 1. The three-capital model measures for sustainable development Source: Adapted by authors [3].

The three-capital model illustrates that the three main pillars underlying sustainability are: economic, social-cultural, and ecological. These are unconditionally interdependent. Only together and/or combined, however, can they have some effect in line with the general principles: bearable, 
equitable and viable. Each of these elements are essential to determining the quality of the capital and ensuring the achievement of the goals of the organization. The requirement includes a number of indicators in order to make it operational [4]. The last point is the criteria for determining the gauge between zero and the target.

Equally relevant are models which, at government or public management levels, take into account that sustainability is a process that induces major changes in all areas of life. This route of cyclic process continually has to be improved. The most popular models [5] highlight that the organizational change must be based on technological, cultural and structural change. These factors of change can be distinguished but not separated: optimization, improvement, renewal. In each of these approaches, a specific interaction between culture, structure and technology can be recognized.

In the process of sustainable development, optimization and improvement with respect to environment have been practiced and developed over the last decades (Figure 2), [6]:

- Culture refers to satisfying the nature, conditions and volume of societal needs to be fulfilled;

- Structure is the ability of the economic and institutional organization to fulfill these needs;

- Technology provides the technical means to fulfill needs efficiently [7].

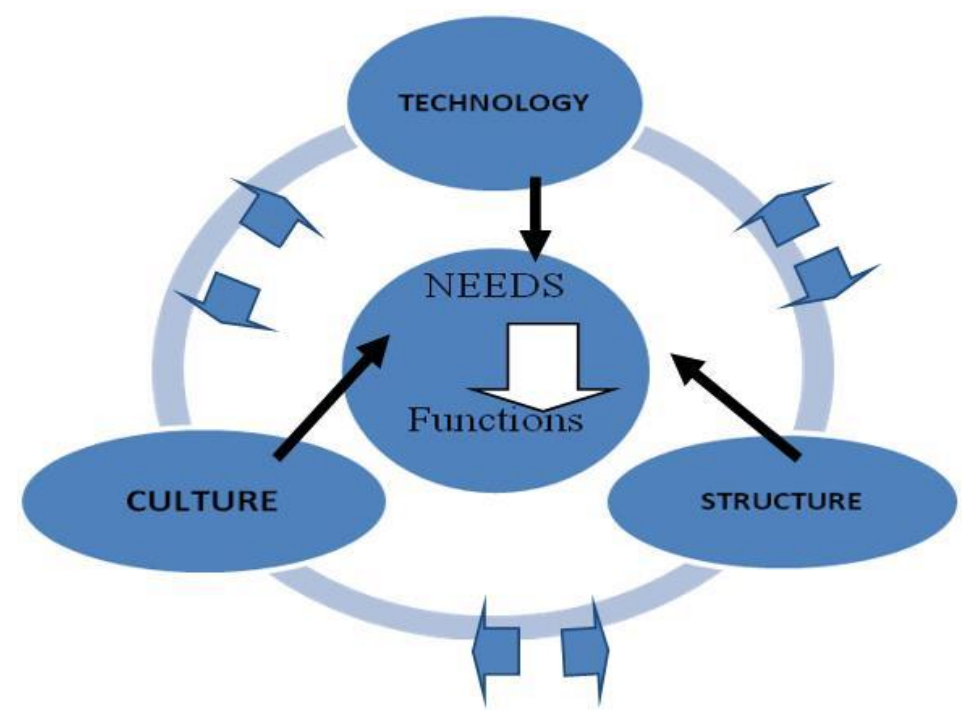

Figure 2. Cyclic components of change in organizations Source: Adapted by authors [8].

Maramures County's current challenges mean that more attention must be paid to the management of change. This may be more easily achieved through the use of new approaches, tools and more effective methods. A paradigm shift is even more difficult if the weaknesses and threats in the region are not sufficiently taken into account, nor are there concrete ways of capitalizing on opportunities, strengths and key capabilities.

\subsection{The Requirements That Must Satisfy the Strategic Model for Sustainable Development}

The strategic approach to sustainable development of local communities must create a social perception that the institutions are to serve the public and not vice versa.

In this context and, compatible with the European model, public management becomes a model for the evolution of the community. 
The sustainable development strategy must be consistent with the principles and laws laid down at the European and global level, based on an integrated approach for change. Europe 2020 strategy is a new vision for Europe's social market economy, supporting European Union countries in getting out of the economic and financial crisis and to generate a sustainable and inclusive economy, with high levels of employment, productivity and social cohesion [9].

The European Union policy is an investment policy that contributes to the implementation of the Europe 2020 strategy with the view of increasing the number of jobs, competitiveness, and economic growth, improving the quality of life, and supporting sustainable development.

\subsection{Objectives of the Paper}

This paper investigates, using several approaches, the possibility to select, based on critical analysis and comparative study, those elements that lead to determining a viable managerial sustainable development "model” for communities in Maramures County, Romania.

The need for a study of sustainable development management arises from the current situation in the county. From the analysis of the existing situation in Maramures County, there are some questions to be asked:

- What is the basic principle that the local government believes could strengthen the selection of sector policies for regional development?

- Has it already initiated an effective governance based on citizen aid, as a generator of ideas, suggestions, and proposals for strategic planning?

- What is the best strategy for balanced development of Maramures County?

- Can we customize a model that integrates strategy in the long term?

In formulating these hypotheses, the paper was structured and systematized to answer these questions.

Ultimately, the authors suggest a model of territorial integrator sustainable development strategy of Maramures County.

\subsection{Analysis of Strategic Elements}

The purpose of the sustainable development strategy for the period 2015 to 2020 is to work towards the continuous improvement of quality of life of both the present generation as well future ones. A diagnosis analysis for defining the main problems and solutions of a community's sustainable development is represented in Figure 3.

The development strategy of Maramures County must be based on a relevant analysis of the existing conditions of the community. The authors of this paper have analyzed the main indicators of sustainable development of Maramures County in the period 2010 to 2014.

Based on the results of the analysis, they have developed a SWOT analysis (strengths, weaknesses, opportunities and threats) in order to ascertain the resources available in Maramures County, the opportunities for sustainable development and the measures which are recommended to avoid the possible risks. 


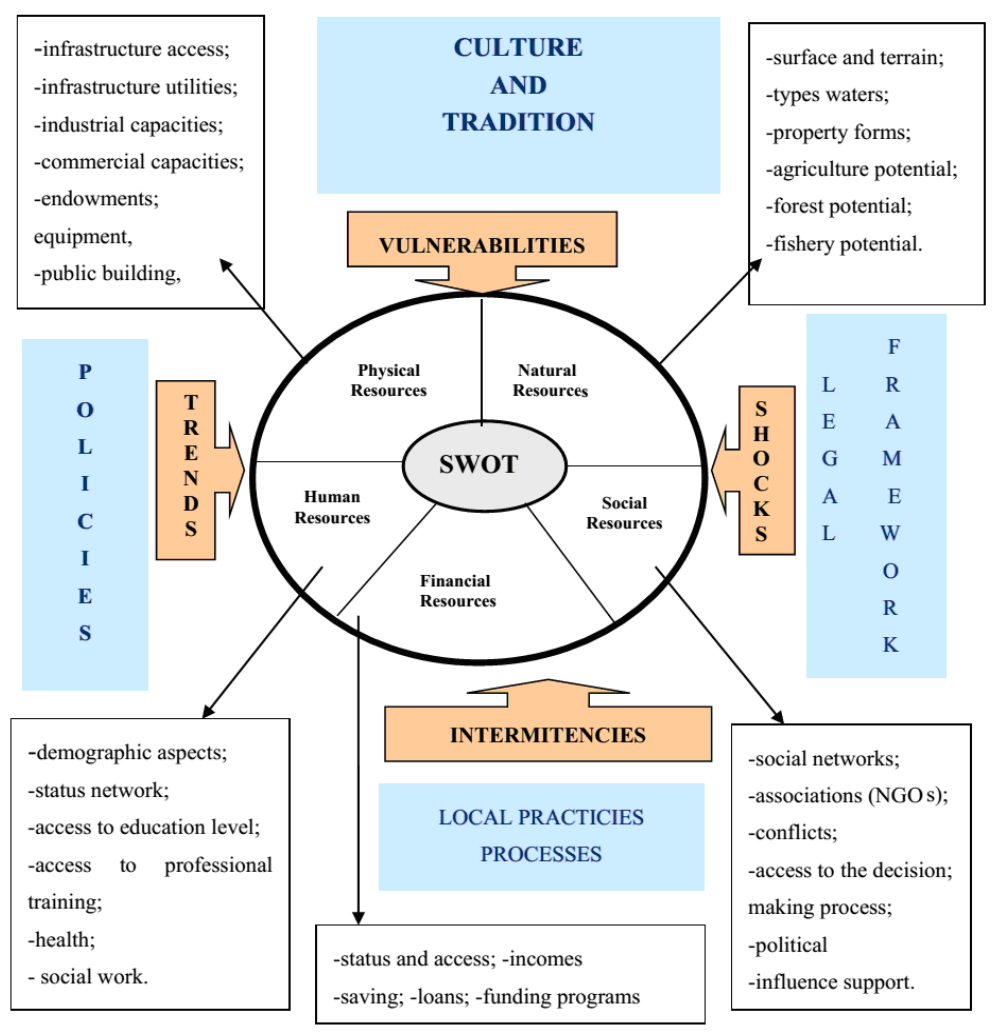

Figure 3. SWOT (strengths, weaknesses, opportunities and threat) analysis of local frame

The authors have developed a detailed analysis of the effects of climate change in Romania, in terms of human resources, agriculture, water resources, the forestry sector, infrastructure, construction, transport, tourism, energy, industry, and the healthcare system.

The indicators presented in this analysis follow the development stage at the level of Maramures County, in the period 2012 to 2014, taking into account the national sustainable development strategy, which is in line with that of the European Union.

1.3.1. Synthetic Indicators of the Main Elements That can Influence Major Strategic Directions of Maramures County

The Analysis of Unemployment in Maramures

The registered unemployment rate at the end of December 2014, at a national level, was 5.29\% and, at the level of Maramures County, was $3.42 \%$. For Maramures County, we can observe a decrease in unemployment with $8 \%$ in 2013 and with $16.7 \%$ in 2012, having a positive impact on the job market. The unemployment in the Transylvania Region, from 2012 to 2014, is presented in Table 1.

Table 1. The number of unemployed people in the region of Transylvania

\begin{tabular}{cccc}
\hline Number of Unemployed People & $\mathbf{2 0 1 2}$ & $\mathbf{2 0 1 3}$ & $\mathbf{2 0 1 4}$ \\
\hline Maramures & 8588 & 7875 & 7153 \\
Bistrita Nasaud & 6642 & 5936 & 5713 \\
Salaj & 6809 & 6278 & 6104 \\
\hline
\end{tabular}

Source: [10]. 
Maramures County has the biggest number of unemployed people from 2012 to 2014, if we compare it with the values of other counties from Transylvania; compared to Bistrita Nasaud and Salaj, Maramures remains on top, which can be explained if we take into consideration the influence of the economic crises and the weakening of industrial and agricultural sectors in the county.

At the end of 2014, Maramures was among the counties with the highest number of pensioners, the number of retirees being higher than that of employees. The ratio in Maramures is 1.23 retiree to 1 employee. The total number of unemployed people at the end of December 2014 was 7153, out of which about 2050 graduated from university in 2014. From the report of Institute of National Statistic (INS) [10], in Maramures, among the 112,489 pensioners in the state social insurance system, the average monthly pension is 823 lei (150 Euro). According to statistics, from the total number of pensioners in the state social insurance system of the county, 22,453 people are listed as pensioners with disability, receiving a monthly average pension of 573 lei (120 Euro). According to the Department of Statistics of Maramures County, at the end of 2014, the distribution of employees by sector shows that the largest share is held by services (52.8\% of the total), followed by industry and construction (45.6\%), agriculture, forestry and fishing (1.6\%). Compared to the end of December 2013, the service sector recorded the most growth with 489 additional people employees. This was followed by the industry and construction sector with 422 additional people, and 15 people for agriculture, forestry and fishing.

The Analysis of Demographic Predictions in Maramures

Demographic predictions for the period 2015 to 2020 show that the preschool and school-aged population will decrease by $28 \%$ : for the 3 to 6 years of age group, by $26.3 \%$; for the 7 to 14 years of age group, and by $38 \%$ for the 15 to 24 years of age group.

The labor market in Maramures County has undergone major transformations in the context of an economic restructuring process from the mining sector manifested by the reduction of the active population and employed population and imbalances caused by the restructuring process of the Romanian economy [11].

Demographic decrease in Maramures County will have important implications for the human resource potential, and for socio-economic development in the period 2015 to 2020.

In Table 2, we have presented the expected evolution of the population and density of population in North-West Development Region using specific values, which will have a negative impact for 2015 of $2.46 \%$ and in 2020 of $5.81 \%$ for Maramures County.

Human resource development is a priority in the period 2015 to 2020 for Maramures County, and implementation of a greater number of human resource development projects through the Human Resource Development Operational Sectorial Programme will generate development.

Remarks: Demographic trends highlight the need for involvement of technical and vocational education providers in the period 2015 to 2030, to provide continuous training for the preparation of the middle-aged groups in order to meet the skills and qualifications required by the labor market, for raising the qualification level, and for achieving partnerships between schools and economic agents. 
Table 2. The predicted evolution of the density of population in the N-W Development Region in the period 2010 to 2020.

\begin{tabular}{cccc}
\hline County & 2010 [people/ $\mathbf{k m}^{2}$ ] & $\mathbf{2 0 1 5}\left[\mathbf{p e o p l e} / \mathbf{k m}^{\mathbf{2}}\right.$ ] & $\mathbf{2 0 2 0}\left[\mathbf{\text { people}} / \mathbf{k m}^{\mathbf{2}}\right.$ ] \\
\hline Sălaj & 24,000 & 23,220 & 22,340 \\
Bistriţa-Năsăud & 31,780 & 31,450 & 30,880 \\
Satu Mare & 36,100 & 35,030 & 33,710 \\
Maramures & 50,740 & 49,490 & 47,790 \\
Bihor & 58,420 & 56,900 & 55,040 \\
Cluj & 66,130 & 63,810 & 61,000 \\
Total & 267,170 & 259,900 & 250,760 \\
\hline \multicolumn{4}{c}{ Source: [10]. }
\end{tabular}

In the education system in Maramures County, investment will be needed in infrastructure and equipping schools with modern equipment and latest-generation teaching materials.

The Analysis of the Dynamics of GDP Growth in Maramures

The analysis of the dynamics of GDP growth in Maramures County in the period 2012 to 2014 reveals that there has been significant growth in the year 2014 compared with 2012. The sustained rate of economic growth in the period 2012 to 2014, reflected in GDP growth, has also generated the moderate growth of labor productivity in Maramures County. Maramures County's economy has suffered from substantial changes lately, especially due to the restructuring of industry sectors that depended mainly on extractive activities. The economic development of Maramures County should consider the revaluation of resources of the County, respecting the balance between entropic and natural environments.

Evolution of GDP growth in Transylvania Region it is presented in Table 3. The evolution of GDP growth between 2012 and 2014 in Maramures County has the lowest value compared with Bistrita Nasaud and Salaj other counties from Transylvania.

Table 3. Dynamic Evolution of GDP in Transylvania Region.

\begin{tabular}{cccc}
\hline Year & $\mathbf{2 0 1 2}$ & $\mathbf{2 0 1 3}$ & $\mathbf{2 0 1 4}$ \\
\hline Maramures & 917,580 & $1,009,900$ & $1,106,850$ \\
Bistrita Nasaud & $2,472,760$ & $2,565,080$ & $2,569,760$ \\
Salaj & $2,419,097$ & $2,511,417$ & $2,516,097$ \\
\hline
\end{tabular}

Source: [10].

Using the statistical data from Table 3, for Maramures County the annual average growth of GDP from 2012 to 2014 was $5.7 \%$, and for 2014 to 2020, it is expected to be $4.9 \%$ and with $4.0 \%$. Forecasts for the period 2021 to 2030 must take into consideration the necessary convergence criteria for adopting the Euro currency and its higher value.

To optimize economic activities and to increase the competitiveness in the business environment of Maramures, in the spirit of sustainable development, special attention will be given to the development of research and innovation activities at the North University Center of Baia Mare and the promotion of technologies for the production of alternative energy, which do not pollute. 
Remarks: In the period 2015 to 2030 in Maramures, great importance will be assigned to the development of the information society and knowledge-based economy, which will promote economic competitiveness, administrative capacity, improved access to information and communication, and social and cultural development of the entire county.

Innovation will generate an increase in products' and services' quality in Maramures County which will become a competitive advantage in the national and European markets and a premise for adaptation to dynamic market demand.

\section{Infrastructure Analysis of Maramures County}

Maramures County has an international airport at Tăuţii Măgherăuş, 5 km from Baia Mare city, which has benefited in 2014 from significant investment in modernizing the runway. In Maramures, there is a good road and railway network.

In the period 2015 to 2020 , the investments will be continued for the development of infrastructure specific to roads and railways and the modernization of railway stations, so that the offered services will be of a higher quality.

Analysis of Tourism in Maramures County

In the period 2012 to 2014, at the level of Maramures County, important actions have been initiated to promote tourism, at both national and European levels. Maramures County has considerable tourism potential: natural reserves, lakes and thermal water resorts, favorable conditions for mountain tourism, for recreation or rest. The abundance of ethno-folkloric areas in Maramures County have generated agro-tourism development. By participating in international trade fairs in Berlin, the products from this county and the brand "Maramures" were promoted. Maramures represents a highly desirable tourist destination at a world level, because of its unique and indisputable heritage values. However, its tourism potential is not being fully exploited. In the period 2015 to 2020, tourism development will be a priority, as the quality and diversity of services and the number of tourists increase.

Analysis of Agriculture and Forestry Sectors in Maramures County

In the period 2012 to 2014, at the level Maramures County, the agricultural sector is characterized by a low labor productivity, low level of mechanization and a lack of strategies oriented to cultivation of economically valuable crops.

The Baia Mare Depression, the meadow of rivers Someş, Lăpuş, Bârsău and Săsar, is an area with a high degree of suitability for agriculture. Argyle and brown clay soils will lead to high production. Less favorable to agriculture are piedmont and hilly areas. They are subject to frequent landslide processes, so degraded land areas are more common.

Remarks: In the period 2015 to 2020, there will be continued anti-erosion and soil conservation works. Hilly areas in Maramures will be used for horticulture, viticulture and animal husbandry. The mountainous region represents a percentage of almost 50\% of the Maramures County area, with large natural pastures, being an area for growing cattle. 
In the period 2015 to 2020 in Maramures County, the development of agricultural activities to European standards, animal husbandry, fruits trees, fish farming, and the integration of agro-industrial production, through the development of the processing sector, will create the potential to enhance competitiveness and sustainable development.

In order to decrease and eliminate discrepancies between rural and urban development, strengthened partnerships between public institutions, NGOs and the economic environment will be required to contribute to the increase in the capacity of development and implementation of projects.

In the period 2015 to 2020, the forestry sector from Maramures County aims to develop a modern management system of forests in protected areas and promote awareness among the population of the importance of forests and the extension of woodland areas.

The development and improvement of management of natural areas will represent the priority in Maramures County during 2015 to 2020, with the view to protect and improve the natural environment.

\section{Case Study: Maramures County, Romania. A Model of Sustainable Development}

\subsection{Strategies for Sustainable Development in Maramures County}

Strategic management covers two major aspects:

- Defining this entity's objectives, strategy, structure and principles of functioning;

- Measuring the impact in space and time of an important decision being made.

Any strategic endeavor is based on a diagnostic analysis of the development framework, which can be synthetically expressed by an analysis methodology frequently used in the world, necessary for defining local strategic priorities [12] composed according to Figure 4.

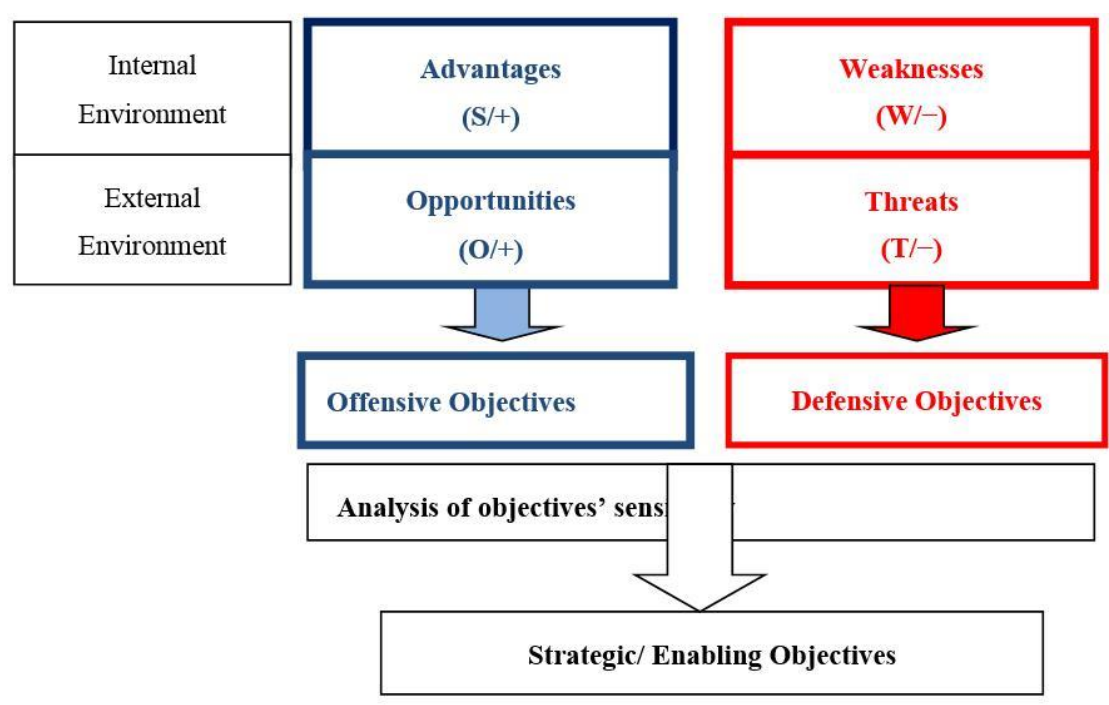

Figure 4. The model of diagnostic analysis in strategic planning.

The main social connections in relation to the suburban environment are determined, as well as to education and training, and are adapted to the needs of the current generation. A reduction of disparities between communities represents a global objective for sustainability; the same need has been identified at the suburban level, in order to ensure life quality comparable to all areas of a community. 
The integrated regional regeneration plan applied in Maramures County for a "contiguous" area is structured according to objectives, development axis, major intervention fields, measures and distinct actions responding in an integrated manner to the social, economic, habitat or environment problems of the identified area. A way to preserve and improve the regional regenerating plan applied to Maramures County is to followed the sustainable life cycle steps (see Figure 5):

Plan: Sustainability Measurement: identifying, analyzing and measuring the regional problems which impact Maramures County;

Do: Sustainability Management developing and testing solutions for our county which assure a long life cycle from 2012 to 2020;

Act: Sustainability Audit: implementing and improving solutions with long term impact;

Check: Sustainability Investments: measuring how effective solutions are and analyzing if they could be improved in any way, using the standards.

The implementation of the integrated plan is a long-term aim, integrating a territory approach, bringing together the sector approaches and directly contributing to the implementation of the Maramures County sustainable development strategy [13].

From these aggregated indicators, a suburban area can be identified and analyzed, directly requiring integrated public intervention or regional regeneration in the short term.

The result or response of the accomplished analysis is materialized, for example, in order to diversify county economy based on natural resources, knowledge and innovation [14-16].

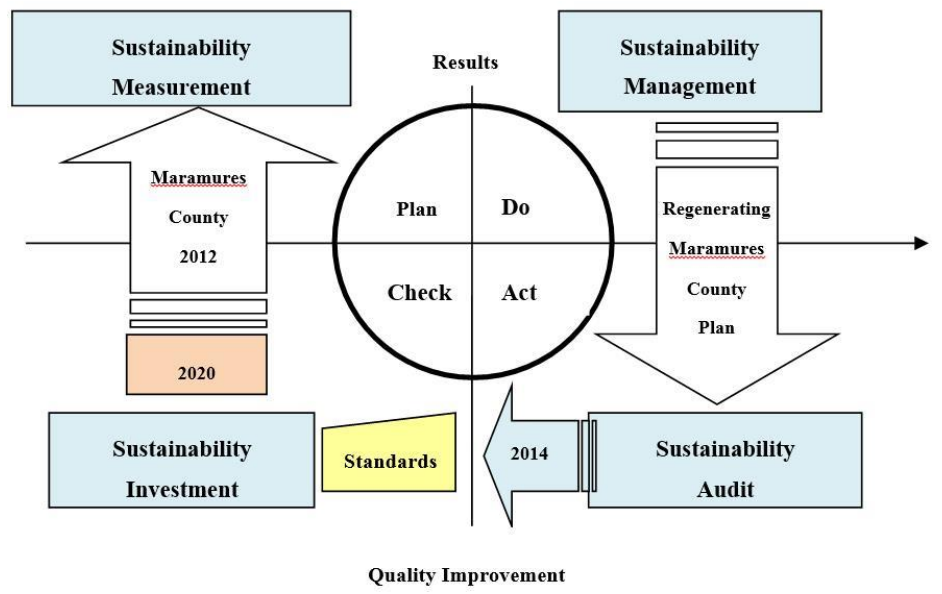

Figure 5. Sustainable Management Life Cycle for Maramures County.

In order to define the ensemble of planned priority projects, the functional links between them are based on two aspects of the approach towards integrated management of the project portfolio:

- Defining areas with maximum urban regeneration potential, the project portfolio is enacted in an integrated manner in these areas (cohesion areas);

- Defining cohesion and/or convergence axes between the defined county intervention area and county adjacent areas (convergence areas);

Considering the need for an integrated approach of the project portfolio for the Maramures integrated county development plan, both from the perspective of integrated projects and the functional 
relations between them, it is imperative that the assembled interventions demonstrate synergy in their impact and results [17].

Strategic planning aims to define the strategic community development benchmarks, to analyzing and evaluating the strategic planning process, and reaching the most important fields of intervention (social, economic, environment) within a structured approached according to the "process" objectives model, presented in Figure 6.

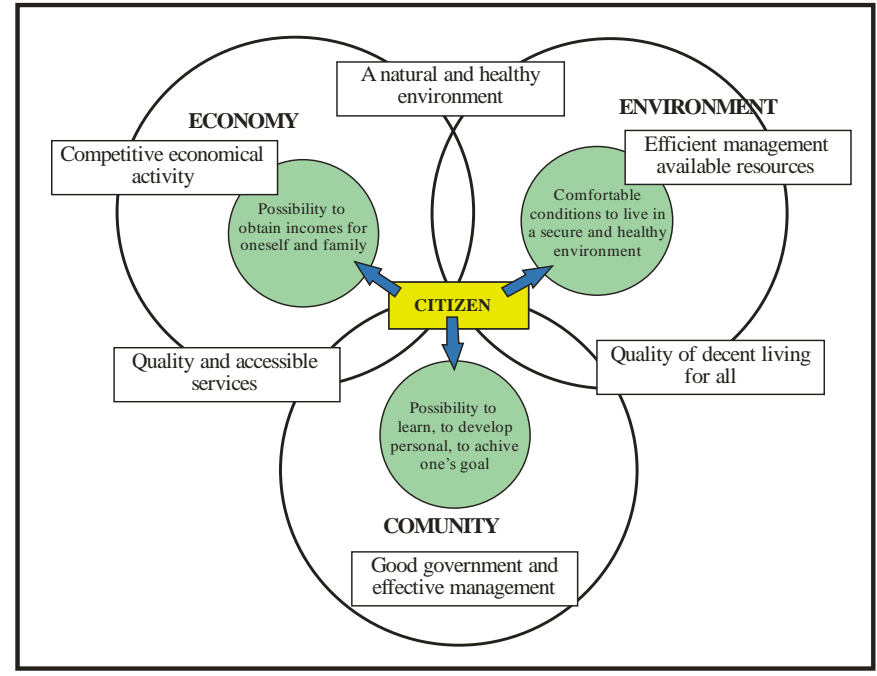

Figure 6. Strategic planning process analysis and evaluation structure

These proposed priority projects have the advantage that, implemented simultaneously in a well-defined urban area, could achieve maximum synergism of the intervention; their joint implementation results being multiplied according to individual results [18].

Strategic objectives and a conceptual axis of the sustainable development strategy are presented in Figure 7.

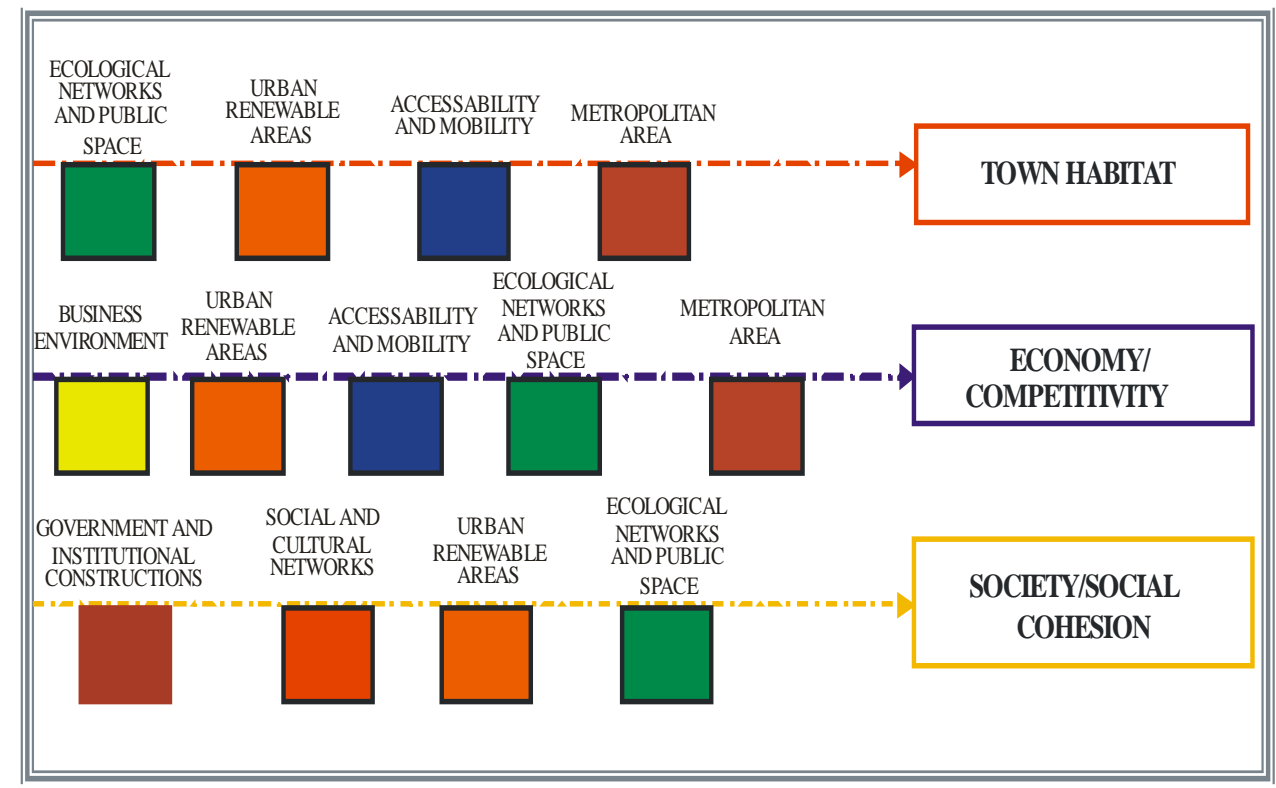

Figure 7. Strategic objectives and conceptual axis of the sustainable development strategy. 
For example, Maramures County reorganized its strategic vision from 2010, by defining in 2014 a series of strategic objectives and an integrated conceptual axis.

The approach of the European Union has evolved from the social dimension to the competitive one (Lisbon Agenda, Leipzig Charta, European Territorial Agenda) thinking at a larger scale (metropolitan scale, growth poles) [19].

Allocated to each strategic objective, according to the locally established strategic planning, policies for sustaining the promotion of public programs have been defined, concerning development in Maramures County.

\subsection{County Observatory-An Efficient Instrument for the Appraisal of Sector Policies}

In order to define efficient sector policies of sustainable development, the study has developed participatory dimensions of community involvement in their own development, through community participation and individual analysis in public decision making, as well as different manifestations and public involvement in this process. This project has been entitled "county observatory."

Sector policies are defined as being a framework of action specific to a field, establishing the steps and procedures to achieve predefined objectives that can be subject to monitoring, evaluation and change.

The county observatory is the latest instrument for involving the community in the development planning process, successfully applied both in the European Union and throughout the world, as well.

The advantages of the county observatory are the following:

- Contribution to the spatial concentration of urban development interventions;

- Sharing strategic vision with the main stakeholders in the field;

- Response to the most important needs of the citizen;

- Building a "workshop" permanently open to all interested parties in the field of developing urban, sector and territorial indicators;

- Building a monitoring system for urban development strategies and policies;

- Setting the basis for making relevant statistical comparisons between urban indicators at county, regional, national, European and world levels.

Through an efficient management of the county observatory, a plan of measures can be developed at the neighborhood level.

This plan represents the development and life quality increase vision for this neighborhood.

Due to the fact that a plan of measures for a well-defined space has to be acknowledged and implemented by all stakeholders (citizens, associations of owners, businesses, NGOs, public administration), the way of acknowledging and institutionalizing this plan of measures can be through a neighborhood contract.

This neighborhood contract is based on:

- Justifying and analyzing problems, developed in the Urban Observatory;

- Identifying adequate solutions for the community through the CIVIC (Creativity, Initiative, Volunteering, Involvement, Consultation) instrument;

- Planning action implementation, allocating resources, and establishing a corporate-type responsibility; 
- Acknowledging the responsibilities of all stakeholders.

The implementation of this contract in Baia Mare City began in 2003, along with the CIVIC project (Creativity, Initiative, Volunteering, Involvement, Consultation), and the year 2010 saw discussion on the implementation of neighborhood contracts.

The partnership technique has been used for the nominations.

Thus, we have chosen a less sophisticated procedure and we have created the possibility for the educated in the field to promote those names, people and/or groups who have contributed to the sustainable development of the community through their activity.

CIVIC events that followed from 2003 to 2015 aimed at fields such as: school systems, architecture, culture, education, and art, completed through a meeting between CIVIC and members of parliament.

In the years that followed, up until now, the number of fields aimed for integration in the CIVIC concept has grown, adding the following to the ones already mentioned: sports, mass media, businesses, NGO, health, economic, urbanism, strategy, tourism, and youth [20].

Using key factors such as "performance recognition" and "continuous competition between values," the CIVIC concept has contributed to the development of communication between local public administration and the community, has promoted intellectual and industrial values, has integrated as much as possible the idea of transparency, and has created strong structures in the sustainable development process.

The multi-annual investment program creates the premise for using resources in obtaining priority objectives by establishing the link between a development strategy and annual budgets, as well as between financial programming and the execution of investment objectives.

Developed and implemented in Maramures County, the program ensures the link between local budgets and its expected allocations, action plan and city development strategy, offering predictability in development and socio-economic stability.

A relevant example is represented by using the multi-annual planning of public funds in increasing the implementation capacity of projects financed from structural funding.

The implementation of the Maramures County integrated urban development plan, simultaneously implementing eight large infrastructure projects, has been financially analyzed taking into account the granting of pre-funding, reimbursement charts, work execution charts and the due costs for a planned implementation for a period of four years.

Using these instruments of planning a major investment, the predicted outcome of public funds management can be controlled and optimally ensured.

\section{Results}

\subsection{Strategic Public Management Instruments. Regional Polycentric Development}

The integrated urban development plan of Maramures County seeks public intervention in well-defined areas requiring regeneration gaps due to social, economic, territorial, and environmental functions from other areas of an urban municipality.

The sustainable development strategy of Maramures County contains the vision and strategic development objectives, the package of policies, programs and projects and the mechanisms for 
implementing a continuous process for a defined period (development, implementation, post-implementation analysis, review).

The metropolitan development strategy supports the role of Baia Mare city in polarizing concepts of regional public management. It is defined as an instrument of public management perspective, in terms of supporting regional polycentric development phenomenon.

Through the theoretical relationship of the three levels of polycentric regional development, a new trend toward effective public management is presented that analyzes relationships and impacts for a sufficiently developed urban community, so as to provide an external influence area (territorial, social, economic and medium) that has its own internal development needs adapted to new challenges (urban regeneration).

These strategic tools are designed to polarize positively an area of influence and define common public policies of neighboring communities, directly related to the external environment, regional, national or European.

The development of the functional relationships versus the isolation of the local communities represents an extremely complex analysis in the current context, whereas the identity and the globalization are two of the phenomena that can be subjected to a complementary analysis through this concept [20]. The general concept regarding a metropolitan area refers to a central territory that includes a densely populated nucleus with the neighboring communities having a high coefficient of socio-economic integration with the central territory. The territorial adjustments in the fields of economy and housing, the conservation and the promotion of natural values, and the development of the basic public infrastructure are some of the major fields of interest.

The Maramures County system aims at establishing:

- A pole for economic growth, dominated by environmentally friendly productive activities (transfer areas and technologic parks) and tourism;

- A comfortable place for living in a non-polluted environment.

A number of issues defining the county system management of Maramures emerged from the diagnostic analysis carried out.

This set of problems will lead us, as a next step, to formulate strategic objectives and policies, programs and development projects:

- the peripheral position in relation to the major transportation corridors;

- the effect of economic restructuring;

- the existence of regional disparities;

- the existence of environmental issues;

- $\quad$ the damaged built heritage; and

- $\quad$ the complexity of public management.

\subsection{Strengths of the Maramures County System}

Considering the elements that are part of the vision of development, the strategic objectives for which the Maramures County system association has been created are:

- improving the quality of life and removing the existing disparities between localities; and 
- creating a pole of economic concentration and support for attracting investment and for further development of jobs in this area.

The society has a pattern of organizing existence that designates the entire field of human action: the social system, the behavioral mechanisms, the individual personality, the physical and organic environment, the cultural system, etc.

Establishing a forum of public debate for the problems of the community at a sectorial level according to areas of interest is evidently a good example for other administrative-territorial units regarding the opportunities, decisions and the prioritizing of the objectives of local development.

These types of instruments are aimed at correlating and correcting the developed policies and public programs so there should be a maximization of the implementation impact as well as an increase in the community's degree of satisfaction towards the ongoing public management.

The quality management system is aimed at improving the quality of public services, on the basis of certain general and specific procedures.

The unitary application of these procedures leads to a more efficient relationship between the public administration and the citizen, developing the analytical capacity of public management [20].

The implementation of this management system in Maramures County has led to an increase in the regional community's confidence in the public services provided by the administration, to the reduction of the red tape and a more efficiently allotted time for specific activities.

The environmental management system is primarily aimed at analyzing the conformity of a public administration's activity in accordance with the local, national or European environmental legislation.

The sustainable development strategy represents a strong political pledge for the future of the community and, at the same time, a platform for the coordination of integrated actions from the urban agenda assumed by the collectivity. The strategy answers the challenges with which communities are faced on a global scale: financial crisis, competitiveness and globalization, a decrease in population and demographic aging, migrations, climatic changes and the management of energy resources, to which are added, at an internal level, the process of decentralization in the education and health systems.

\subsection{Integrated Approach of the Maramures County System}

The approach of the sustainable development strategy of Maramures County has as its foundation the global and European experience in the domain of strategic territorial planning, within the context of promoting the sustainable development of cities.

In the process of drawing the sustainable development strategy of Maramures County, there was used, for the first time in Romania, the poster-plan type of cartography that presents the main strategic choices until 2020. It is a synoptic document which projects the future of the community, a perspective document which puts into the limelight both the conceptual axes of the county development and the zones envisaged for intervention for subsequent years.

The territorial development incorporates a new approach within which the social, economic and territorial dimensions are treated in an integrated manner in the context of sustainable development. The decisions regarding measures for development are made under multiple pressures, and the phenomena that manifest themselves locally have an ever-growing territorial dynamic. 
Romania's development is based on a powerful system of major development poles connected to a complementary system of support through a good partnership between the different levels to ensure socio-economic and territorial cohesion, as well as sustainable development. In this context, it is necessary to consolidate a coherent network of development centers which are to act as development engines, and also as an equilibrium structure, at the regional level in Romania.

The analysis of the functional structures at the level of city halls from Romania presents a very heterogeneous image due to the great number of solutions chosen for their own functional structures.

The organization models must be coherently and flexibly organized in order to adapt to the inherent challenges determined by new capacities and responsibilities as regards the processes of strategic planning, preparation of strategic documents, resources access and projects' implementation.

The development of the management capacity of local public administration institutions requires the use of some modern management instruments that shall lead to an increase of the administrative capacity at the local level [20,21].

The promotion of polycentric and balanced territorial development as an essential element for the territorial cohesion realization represents one of the priorities of the strategy of Europe 2020 (Figure 8).

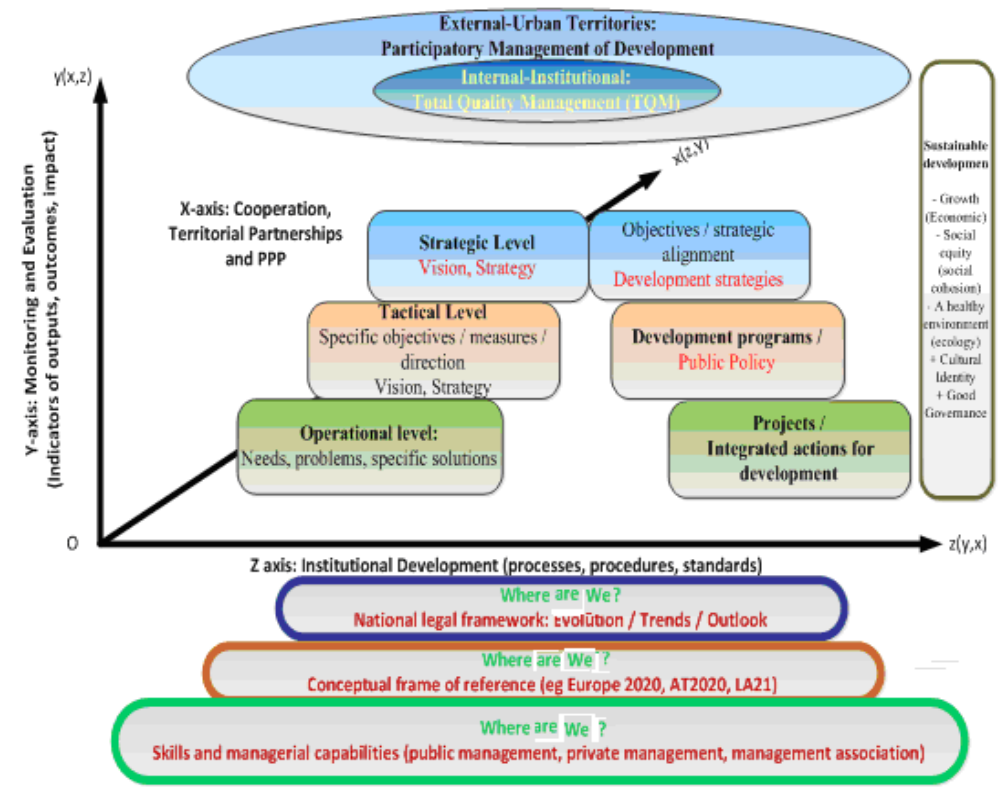

Figure 8. A model axis of sustainable development

In this context, the formation and consolidation of the development poles as basic elements for the creation of polycentric networks must be supported by integrated politics at local and regional levels.

For the implementation of policies related to the integrated polycentric development network, instruments specific to the territorial spatial planning (investment programs, territorial plans, monitoring of territorial development), non-spatial (budget, finances, administrative capacity) and strategic planning (strategies of regional development, coordination mechanisms, politics substantives, strategic planning) are used [21].

The Maramures County System presented in this paper has all the characteristics of a model structure of polycentric development that has elaborated/formulated a development pathway for the 
long and medium-term with all the strategic, tactical and operational elements that support the development within a well-defined territory.

The approach for both components (institutional, territorial) has a complex character but, at the same time, a unitary one.

The scheme for the integrated approach of public management presents the symbolic, visual image of the integrated, systemic construction of the entire work, dedicated to the role and purpose of public management: development of the public administrative institutions as a fundamental public instrument of the evolution of administrative territorial units that shall represent thereof and implicitly the social and economic satisfaction level of Maramures County.

Thus, a useful co-operation between the fundamental actors of the community that must participate in formulating the development pathway and the elaboration and implementation of all fundamental documents that contribute to the increase of regional capacity of development is achieved.

The development process of public management based on the application of "The triangle of knowledge" presents the following advantages (Figure 9):

- It uses the advanced research (over the long term) and the theoretical foundation of the modernization instruments' construction of the public administration ensured by the "university" partner;

- It ensures the optimizing process and efficiency of the construction and practical application (adaptation to the beneficiary's specific) of the public management instruments, ensured by CDI specialized in different fields - technology of information and communication, human resources, public relations, public politics, financial management);

- It represents an answer given by the practical application of the public management instrument that shall lead to the evolution of the theoretical framework of public management, ensuring its continuous development and adaptation to the modifications of public institutional environment from Romania;

- It contributes to the creation of a legislative framework adapted to real needs, tested by the national public system and not based on prognoses or opinions of experts; and

- It allows the facilitation of a legislative framework whose norms were pre-tested by pilot projects and agreed upon by beneficiaries.

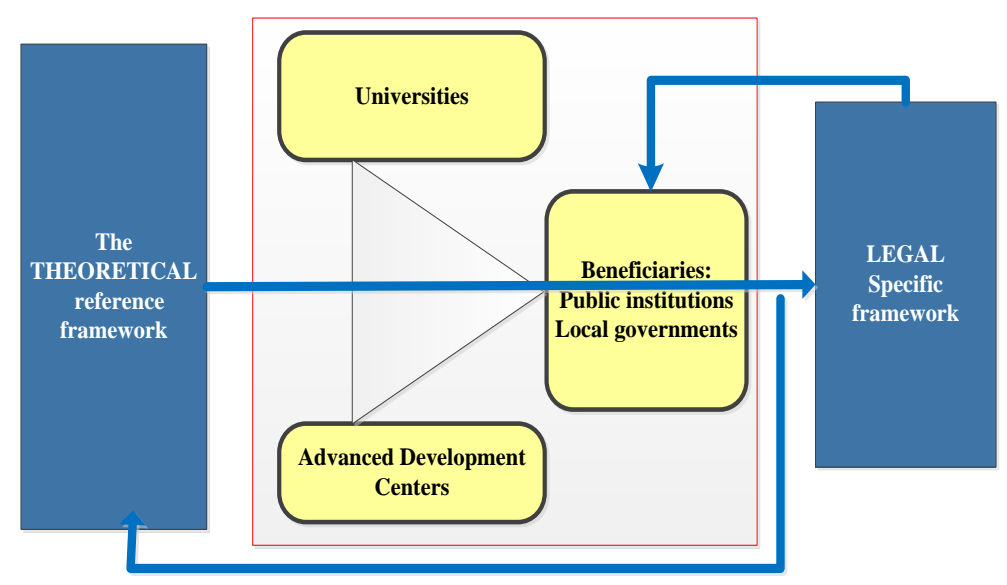

Figure 9. The theoretical and legal framework model "The triangle of knowledge." 


\subsection{Model for Strategy Elaboration}

The base model used for the formulation of the strategy was used in all phases of the measurements, starting from a simplified model with approaches in two directions represented by the SWOT analysis part (analytical approach), and the visionary measurements (overview, mission, strategic targets) (see Figure 10).

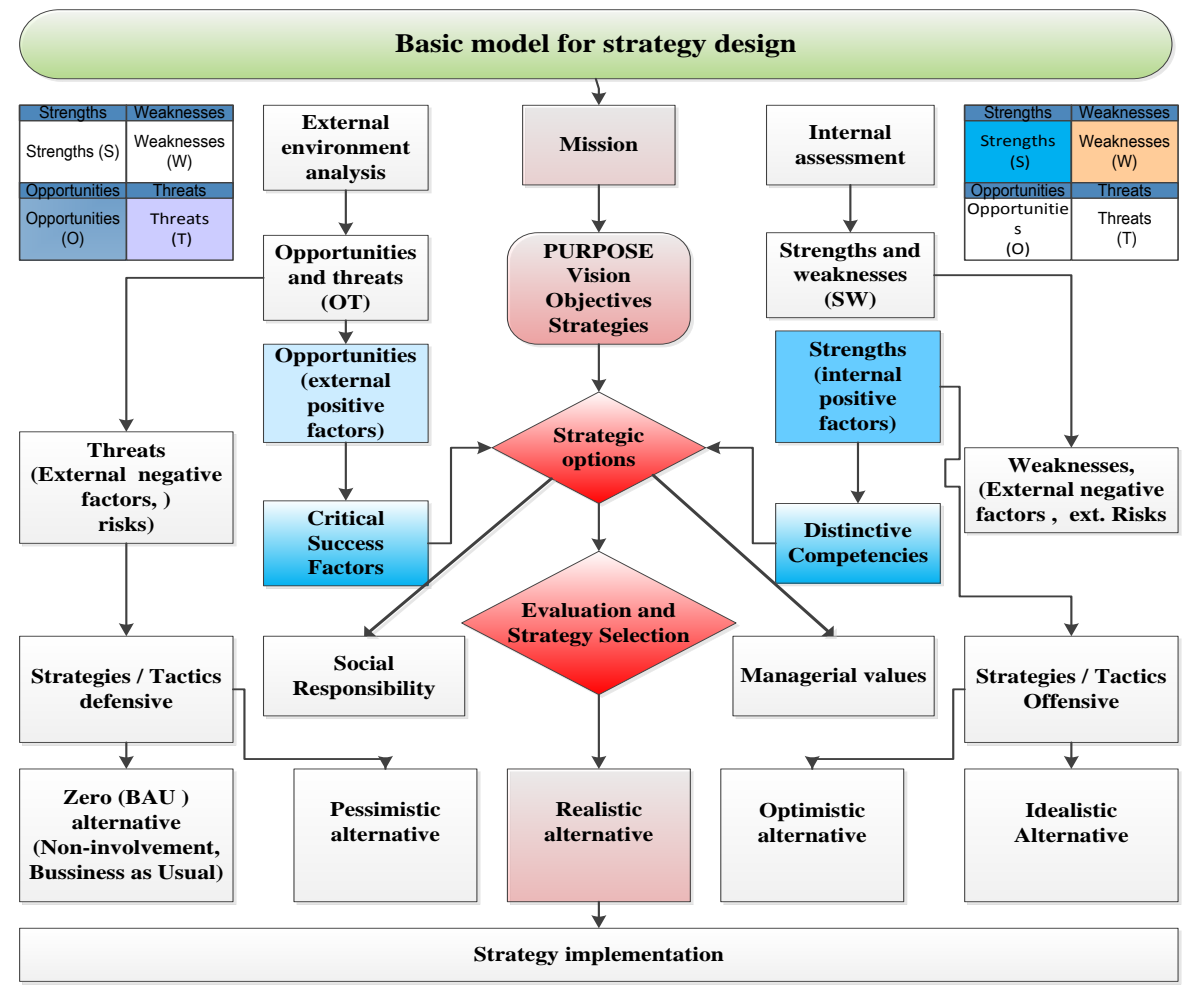

Figure 10. Model for strategy elaboration.

The two approaches have finally generated five types of strategic alternatives (zero alternative, pessimistic alternative, optimistic alternative, realistic and visionary alternative). The model emphasizes the two great types of approaches (defensive and offensive), important especially in tactical phases that aim at medium-term targets. Another advantage of the model is the emphasis of the distinctive competitiveness and competent elements as critical factors of success, respectively, the social responsibility and managerial values as important elements within the complete strategic approach.

Using a series of public management instruments, we have elaborated an Integrated Concept of Local Territorial Development that may be considered and used as a model for any local community dealing with afferent complexity [20] (Figure 11).

The integrated model concept presents the content stages of local development planning, with the influence of local operational, tactical and strategic impacts.

Also, a series of public management instruments are interconnected in order to realize a unitary construction that covers the entire problematical aspects of a community, in our study of Maramures County. 


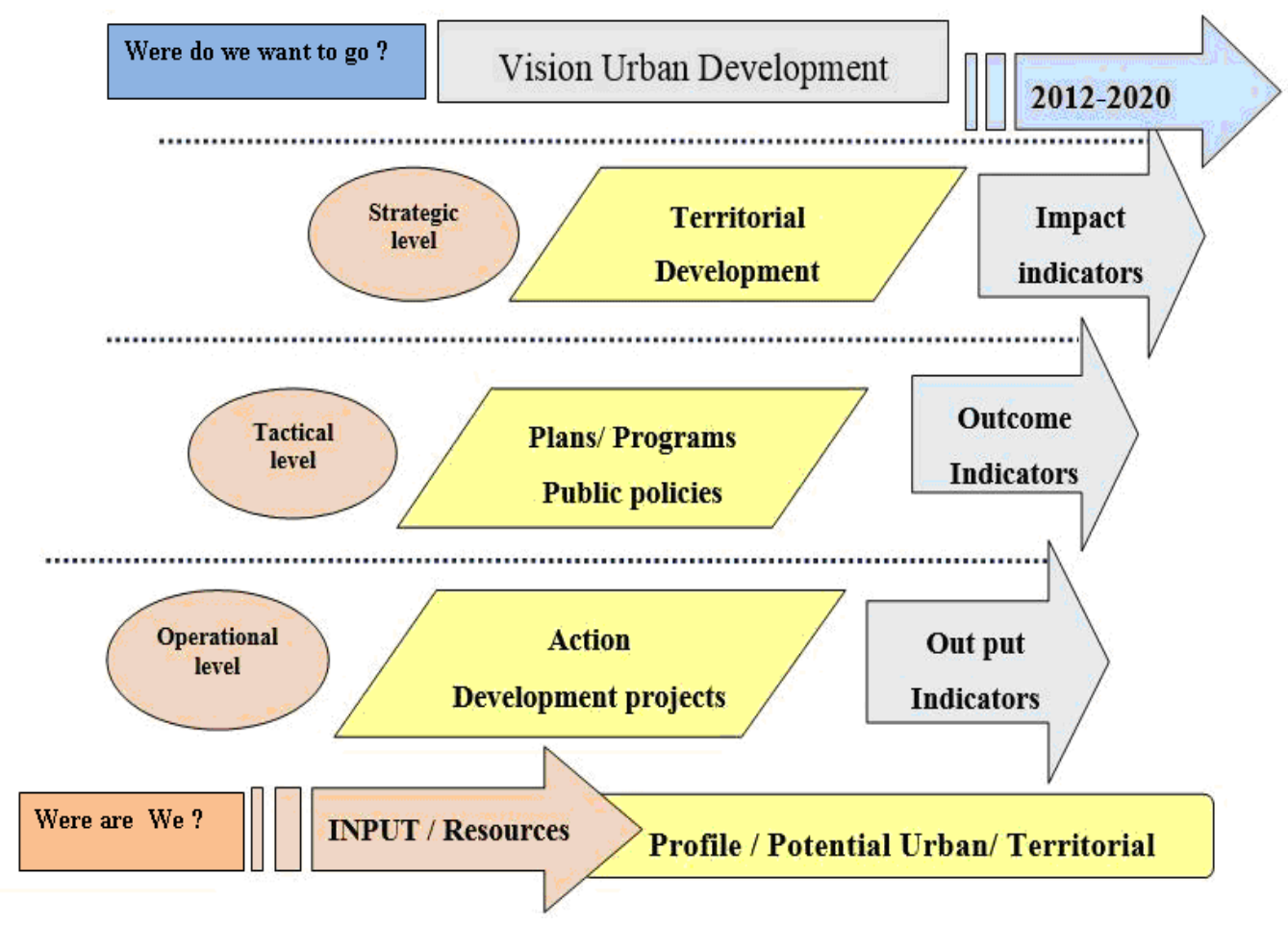

Figure 11. Local Concept of Territorial Integrated Development.

If public management is to improve its use of public administration policies which define the local/urban profile, it should apply the SWOT/PEST analysis to evaluate the potential development of a territory and planning the local process. The improvement model takes into consideration:

- the input/output indicators (services, final products, added values), which are defining the resources level;

- the feedback results, with short-term impacts on specific target groups, defining the successful projects results, planning and establishing specific objectives for measuring results; and

- the impact indicators, defining in the long term the effects on specific target groups and the community, taking into consideration the appeal of strategic objectives.

\section{Conclusions}

The overall objective of sustainable development in Maramures County is to find a balance between interacting systems — economic, human, environmental and technological — in a dynamic, flexible and functional process.

Starting from the analysis of sustainable development presented in Section 2, the authors of the present paper propose the review of the present needs in light of sustainability objectives.

In this paper, modern management tools were recommended to analyze the potential dimensions of community involvement in development, by analyzing individual and community participation in public decision making. Within this context, the model of county observatory was proposed to improve the involvement of citizens in the strategic planning of the region. 
New trends worldwide and the multidimensional aspects of sustainable development of communities were the subject of a new strategic research system, through a regional polycentric approach, which generated a new integrator model proposed by the authors.

The development strategy of Maramures County for the period 2015 to 2030 will place great emphasis on superior exploitation of material values and human resources to support economic and institutional development, which would lead to the reduction of the discrepancies between the levels of socio-economic development of the communities from this county.

In the long term, the strategic objective for the development of the county will focus on the improvement of living standards and the overall development of the county so that Maramures will become a competitive European region, attractive to tourists and investors, and known for its economic, social and cultural valences.

Sustainable development in Maramures County during 2015 to 2020 will be the responsibility of the entire community, from public institutions to the citizens. The existence of a functional county public administration will be crucial for sustainable development.

Sustainable growth in Maramures County will reduce the discrepancies between Romanian counties and the regions of EU countries, in terms of quality of life and it will ensure better cohesion at the county, national and European levels. The success of sustainable development in Maramures County during 2015 to 2020 will depend to a great extent on the qualification of human resources, the know-how, infrastructure improvements, innovation in the production sector, the administrative processes in everyday life, the promotion of local products and market development for a new generation of products and services.

An important role in sustainable development in Maramures County will be assigning to continuing education, for the acquisition of new communication, risk management, and business management skills, for a more effective functioning which is adapted to continuous changes in market conditions and for ensuring competitiveness in all fields. The development of the SME sector in Maramures and an innovative approach to the production process will result in the creation of new jobs and products with high added value. Sustainable development of the mountain region of Maramures will involve activities which generate socio-economic benefits, but with the sustainable conservation of resources to the benefit of future generations.

In Maramures, improving waste management will remain a priority in the period 2015 to 2020 . In this context, the campaigns promoting awareness, information and education on the importance and practice of selective collection will be continued.

Local systems of selective collection will be upgraded and expanded to increase processing and storage capacity of waste and the recovery of reusable materials.

The success of the sustainable development strategy in Maramures County during 2015 to 2020 will depend on the community's ability to form effective working teams that will successfully implement European projects, and properly monitor and evaluate the outcomes, which will generate an increase in the quality of life. 


\section{Acknowledgments}

We are grateful to support from the North Center University of Baia Mare and Local Administration of Baia Mare, Maramures County, partners under the bilateral agreement. We also acknowledge the efforts of the reviewers.

\section{Author Contributions}

These authors contributed fully and equally to this work. They conceived and designed this study together, collected and analyzed the data. All authors wrote the body of the paper and approved the final manuscript.

\section{Conflicts of Interest}

The authors declare no conflict of interest.

\section{References}

1. Baker, S. Sustainable Development; Routledge: London, UK, 2006; p. 245

2. Gareth, R.J. Organizational Theory, Design, and Change, 7th ed.; Prentice Hall: London, UK, $2010 ;$ p. 521.

3. Giddings, B.; Hopwood, B.; O’Brien, G. Environment, economy and society: Fitting them together into sustainable development. Sustain. Dev. 2002, 10, 187-196.

4. Daly, H.E. Toward some operational principles of sustainable development. Ecol. Econ. 1990, 2, 1-6.

5. World Bank. Sustainable Development. Available online: http://www.worldbank.org/en/topic/ sustainabledevelopment (accessed on 17 January 2015).

6. Keoleian, G.A.; Menerey, D. Sustainable development by design: Review of life cycle design and related approaches. Air Waste 1994, 44, 645-668.

7. Gladwin, T.N.; Shelomith, J.K.; Krause, T.-S. Shifting paradigms for sustainable development: Implications for management theory and research. Acad. Manag. Rev. 1995, 20, 874-907.

8. Postman, N. Techno-Poly: The Surrender of Culture to Technology; Vintage Books Edition: New York, NY, USA, 2011.

9. European Commission. Horizon 2020 Programme. Available online: http://ec.europa.eu/ programmes/horizon2020/en/what-horizon-2020 (accessed on 17 January 2015).

10. Institutul National de Statistica. Available online: http://www.insse.ro/cms/files/Web_IDD_BD_ro/ index.htm (accessed on 18 January 2015).

11. Matei, L. Strategii de Dezvoltare Economică Locală. Abordare Managerială; Editura Politeia: Bucureşti, Romania, 2004; p. 516.

12. Rosenbloom, D.H. Public Administration-Understanding Management, Politics, and Law in the Public Sector; Mc Graw-Hill Inc.: New York, NY, USA, 2004.

13. Johnson, C.N. The Benefits of PDCA. Quality Progress Journal. Available online: http://asq.org/ quality-progress/2002/05/problem-solving-the-benefits-of-pdca.html (accessed on 23 January 2015). 
14. Melese, F.; Blandin, J.; OKeefe, S. A new management model for government: Integrating Activity Based Costing, the Balanced Scorecard, and Total Quality Management with the Planning, Programming and Budgeting System. Int. Public Manag. Rev. 2004, 5, 103-131.

15. Anghel, C. Dezvoltarea durabilă la nivel local şi regional din perspectiva integrării în Uniunea Europeană. In Proceedings of the International Conference Dezvoltarea economică, amenajarea şi atractivitatea teritoriului la nivel local şi regional, Cluj Napoca, Romania, 23 June 2006. (In Romanian)

16. Tushman, M.L. Winning through innovation. Strateg. Leadersh. 1997, 25, 14-19.

17. Cash, D.W.; Clark, W.C.; Alcock, F.; Dickson, N.M.; Eckley, N.; Guston, D.H.; Jäger, J.; Mitchell, R.B. Knowledge systems for sustainable development. Proc. Natl. Acad. Sci. USA 2003, 100, 8086-8091.

18. Stankosky, M. Creating the Discipline of Knowledge Management: The Latest in University Research; Butterworth-Heinemann Publishing: London, UK, 2004.

19. Council for European Studies. European Regional Policy in Romania. Available online: http://ec.europa.eu/regional_policy/ (accessed on 18 January 2015).

20. Anghel, C.; Bolchis, R. Sistemul Urban Baia Mare-Suport al dezvoltării policentrice regionale. In Proceedings of International Conference Sustainable Development Strategies, Baia Mare, Romania, 20 May 2006. (In Romanian)

21. Van Zeijl-Rozema, A.; Cörvers, R.; Kemp, R.; Martens, P. Governance for sustainable development: A framework. Sustain. Dev. 2008, 16, 410-421.

(C) 2015 by the authors; licensee MDPI, Basel, Switzerland. This article is an open access article distributed under the terms and conditions of the Creative Commons Attribution license (http://creativecommons.org/licenses/by/4.0/). 